\title{
Pimozide augments bromocriptine lethality in prolactinoma cells and in a xenograft model via the STAT5/cyclin D1 and STAT5/Bcl-xL signaling pathways
}

\author{
ZHENGZHENG XIAO $^{1}$, JING LIANG ${ }^{2}$, QING DENG $^{2}$, CHAOJUN SONG $^{1}$, XIAOLI YANG $^{3}$, ZEBIN LIU $^{1}$, \\ ZHENG SHAO $^{1}, \mathrm{KUN} \mathrm{ZHANG}^{4}$, XIAOBIN WANG ${ }^{5}$ and ZHENGWEI $\mathrm{LI}^{6}$
}

${ }^{1}$ Department of Neurosurgery, Henan Key Laboratory of Cancer Epigenetics, Cancer Institute, Departments of ${ }^{2}$ Pathology

and ${ }^{3}$ General Practice, The First Affiliated Hospital and College of Clinical Medicine of Henan University

of Science and Technology, Luoyang, Henan 471003; ${ }^{4}$ Spine Tumor Center, Department of Orthopedic Oncology,

Changzheng Hospital, Second Military Medical University, Shanghai 210011; ${ }^{5}$ Department of Urology,

Carson International Cancer Centre, Shenzhen University General Hospital and Shenzhen University

Clinical Medical Academy Centre, Shenzhen University, Shenzhen, Guangdong 518000; ${ }^{6}$ Department of Neurosurgery,

Zhongnan Hospital of Wuhan University, Wuhan, Hubei 430071, P.R. China

Received May 29, 2020; Accepted September 21, 2020

DOI: $10.3892 / \mathrm{ijmm} .2020 .4784$

\begin{abstract}
As hyperprolactinemia is observed in patients with bromocriptine-resistant prolactinoma, prolactin (PRL) has been implicated in the development of bromocriptine resistance. Since PRL primarily mediates cell survival and drug resistance via the Janus kinase-2 (JAK2)/signal transducer and activator of transcription 5A (STAT5) signaling pathway, the STAT5 inhibitor, pimozide, may inhibit cell proliferation and reverse bromocriptine resistance in prolactinoma cells. In the present study, compared with bromocriptine or pimozide alone, the combination of pimozide and bromocriptine exerted enhanced reduction in cell growth and proliferation, and increased apoptosis and cell cycle arrest in bromocriptine-resistant prolactinoma cells. A reduction in phospho-STAT5, cyclin D1 and B-cell lymphoma extra-large (Bcl-xL) expression levels were observed in cells treated with the combination of drugs. In addition, pimozide suppressed spheroid formation of human pituitary adenoma stem-like cells, and reduced the
\end{abstract}

Correspondence to: Dr Zhengzheng Xiao, Department of Neurosurgery, Henan Key Laboratory of Cancer Epigenetics, Cancer Institute, The First Affiliated Hospital and College of Clinical Medicine of Henan University of Science and Technology, 24th Jinghua Road, Luoyang, Henan 471003, P.R. China

E-mail: xiaozhengly@163.com

Dr Zhengwei Li, Department of Neurosurgery, Zhongnan Hospital of Wuhan University, 169th Donghu Road, Wuhan, Hubei 430071, P.R. China

E-mail: lizhengwei1006@163.com

Key words: Pimozide, prolactin receptor, bromocriptine, prolactinoma protein expression of the cancer stem cell markers, CD133 and nestin. Pimozide did not exert any additional antitumor activity in STAT5-knockdown primary culture cells of human bromocriptine-resistant prolactinomas. Furthermore, Pimozide combined with bromocriptine treatment significantly reduced human prolactinoma xenograft growth. Western blot and immunohistochemical analyses also demonstrated significant inhibition of cell proliferation and stem cell marker proteins in vivo. Collectively, these data indicated that pimozide treatment reduced prolactinoma growth by targeting both proliferating cells and stem cells, at least in part, by inhibiting the STAT5/Bcl-xL and STAT5/cyclin D1 signaling pathways.

\section{Introduction}

Prolactinomas are the most common type of hormone-secreting pituitary tumors, which cause hyperprolactinemia (1). Patients with prolactinomas usually exhibit symptoms of sexual dysfunction, menstrual disturbance and infertility, and prolactinomas account for $\sim 50 \%$ of all patients with pituitary adenomas which are brought to medical attention $(2,3)$. Bromocriptine is generally considered to be the first-choice treatment for patients with prolactinoma (4). However, at least $30 \%$ of patients do not respond to bromocriptine (5). Thus, improved systemic therapeutic approaches are urgently required. Recent studies have suggested a rational combination strategy consisting of a chemosensitizing agent and bromocriptine to fill this therapeutic void (5).

In our clinical practice, increased prolactin (PRL) levels were observed in patients with bromocriptine-resistant prolactinoma (5). Several studies have also revealed that PRL serves important roles in cell dissemination, survival and drug resistance of prolactinomas (6,7). PRL binds to the prolactin receptor (PRLR) forming a complex which further activates the classical prolactin (PRL)/Janus 
kinase-2 (JAK2)/signal transducer and activator of transcription 5A (STAT5) pathway (8). Thus, the JAK2/STAT5 pathway may contribute to drug resistance in prolactinomas. Furthermore, basal activation of PRL/JAK2/STAT5 signaling has been observed in chemoresistant tumors (9). Based on this background, it is hypothesized that blocking this signaling pathway may reverse bromocriptine resistance. Among the possible inhibitors of the PRL/JAK2/STAT5 signaling cascade components, the STAT5 inhibitor, pimozide, an orally active antipsychotic drug approved by the Food and Drug Administration (FDA) in September 2011 was investigated in the present study $(10,11)$. Pimozide has long been used to treat motor tics and schizophrenia $(10,11)$. It is widely used in our clinical practice due its high clinical safety, low risk of side effects and reasonable price. Pimozide acts on neurons in the CNS by blocking dopaminergic, serotonergic and other central nervous system receptors (12). Recent studies have also suggested that pimozide inhibits cancer growth in neuroblastoma, lymphoblastoma, breast cancer and non-small cell lung cancer (13-17). As pimozide can cross the blood-brain barrier (12), it is hypothesized that it may reduce/eliminate bromocriptine resistance in prolactinoma cells.

The aim of the present study was to evaluate the activation status of the JAK2/STAT5 signaling pathway in bromocriptine-resistant prolactinoma tissues and to assess the potential chemotherapeutic sensitizing effect of pimozide on the bromocriptine-resistant prolactinoma cells. As tumor stem cells serve a vital role in tumor recurrence, metastasis and drug resistance $(16,18,19)$, the effect of pimozide on prolactinoma cell stemness was also assessed.Collectively, these experiments provide a rationale for further clinical studies on the use of pimozide as a chemosensitizer in bromocriptine-resistant prolactinomas.

\section{Materials and methods}

Reagent and antibodies. CD133 (product code ab16518), nestin (product codes ab105389 and ab6142), SRY-box transcription factor 2 (Sox2) (product code ab93689), B-cell lymphoma extra-large (Bcl-xL) (product code ab32370) and Ki67 (product code ab16667) antibodies were obtained from Abcam. PRLR (product no. 13552), Stat5 (product no. 94205), p-Stat5 (Tyr694; product no. 9359), Akt (product no. 4691), p-Akt (Ser473; product no. 4060) and p-JAK2 (Tyr1007/1008; product no. 3776) primary antibodies were purchased from Cell Signaling Technology, Inc. Erk2 (sc-1647), p-ERK (cat. no sc-7383), JAK2 (cat. no. sc-390539), cyclin D1 (cat. no. sc-8396), and $\beta$-actin (cat. no. sc-81178) primary antibodies were purchased from Santa Cruz Biotechnology, Inc. Horseradish peroxidase (HRP)-conjugated goat anti-mouse IgG (cat. no. G-21040) and goat anti-rabbit IgG (cat. no. G-21234) secondary antibodies were purchased from Thermo Fisher Scientific, Inc.

Prolactinoma specimens. Currently, bromocriptine is used as an initial therapeutic agent in China, while cabergoline has not been approved for clinical application yet (20). Thus, in the present study, bromocriptine resistance was defined as the failure to normalize PRL levels or to reduce tumor size by $\geq 50 \%$, after a 3 -month course of bromocriptine
( $\geq 15 \mathrm{mg} /$ day) $(3,5)$. All patients ( 9 men, 7 women; age range 16-63; mean age 43.50, interquartile range, 38-51 years) received surgery between July 2013 and July 2019 at the Department of Neurosurgery, The First Affiliated Hospital of Henan University of Science and Technology (HUST). Eight patients with prolactinoma who had received bromocriptine first-line treatment following relapse, and eight control patients who responded positively to bromocriptine therapy, but who also received surgery for large tumors or poor medical compliance, were included in the present study. The diagnoses of clinical prolactinoma were according to clinical and hormonal evaluation, histological assessment and PRL exclusive immunoreactivity. The PRL blood levels of the patients ranged from 154 to $232 \mu \mathrm{g} / \mathrm{l}$ before receiving medication. For each sample, the tissue was bisected; one half was frozen for protein and RNA extraction, and the other half was fixed and embedded in paraffin. Tissue sections were fixed with $10 \%$ neutral buffered formalin (cat. no. DF0111; Beijing Leagene Biotechnology Co., Ltd.) overnight at room temperature (RT) followed by an embedding in paraffin wax. Sections, 4- $\mu \mathrm{m}$ thick, were deparaffinized with xylene and then rehydrated with distilled water through an ethanol series. Informed consent was obtained from all patients recruited, and the study protocol was approved by the Research Ethics Committee of the First Affiliated Hospital of HUST Institutional Review Board (approval no. 2013-08).

Cell culture. Rat prolactinoma MMQ cells were purchased from the China Infrastructure of Cell Line Resources, Institute of Basic Medical Sciences, Chinese Academy of Medical Sciences. The bromocriptine-resistant MMQ/BRO cells were established by exposing MMQ cells to increasing concentrations of bromocriptine (5-100 $\mu \mathrm{M}$; CAS 25614-03-3; Santa Cruz Biotechnology, Inc.) for 6 months, and the resultant cell line was termed MMQ/BRO. MMQ/BRO cells were continuously cultured with BRO $(15 \mu \mathrm{M})$ to preserve their resistance. All cells were maintained in DMEM/F12 culture medium (Wuhan Boster Biotechnology Co., Ltd.) supplemented with 5\% fetal bovine serum (FBS; Wuhan Boster Biotechnology Co., Ltd.), 10\% horse serum (Wuhan Boster Biotechnology Co., Ltd.), penicillin and streptomycin $(100 \mu \mathrm{g} / \mathrm{ml}$ each; Genom Biotech Pvt., Ltd.) in a humidified incubator at $37^{\circ} \mathrm{C}\left(5 \% \mathrm{CO}_{2}\right)$.

Primary culture of pituitary adenoma tissue. The pituitary adenoma tissue was cultured as described in our previous study (21). Following surgery, the tissue was enzymatically digested using a Human Tumor Dissociation kit (cat. no. 130-095-929; Miltenyi Biotec, Inc.). After dissociation, the tissue was filtered using anti-human Fibroblast MicroBeads (cat. no. 130050601; Miltenyi Biotec GmbH). Subsequently, $1 \times 10^{6}$ cells/well were cultured in complete DMEM/F12, supplemented with penicillin 100 units, streptomycin $100 \mathrm{~g} / \mathrm{ml}, 15 \mathrm{mM}$ HEPES, 3,151 mg/l glucose, $55 \mathrm{mg} / \mathrm{l}$ sodium pyruvate, $365 \mathrm{mg} / \mathrm{l} \mathrm{L-glutamine,} \mathrm{1,200} \mathrm{mg/l} \mathrm{sodium}$ bicarbonate, $\mathrm{pH}$ 7.0-7.4 (cat. no. PYG0085; Wuhan Boster Biotechnology Co., Ltd.).

Isolation of $\mathrm{CD} 133^{+}$nestin ${ }^{+} \mathrm{MMQ}$ cells. As described in our previous study (21), MMQ cells were isolated using CD133 (cat. no. 130097049; Miltenyi Biotec, Inc.) and Anti-Nestin 
Magnetic Beads (cat. no. MB106970-T46; Sino Biological, Inc.). The cells were cultured in DMEM/F12 medium supplied with N2-supplement (5 ml; cat. no. 17502048; Invitrogen; Thermo Fisher Scientific, Inc.), penicillin 100 units, streptomycin $100 \mathrm{~g} / \mathrm{ml}, 15 \mathrm{~mm}$ HEPES, $3151 \mathrm{mg} / \mathrm{l}$ glucose, $55 \mathrm{mg} / \mathrm{l}$ sodium pyruvate, $365 \mathrm{mg} / \mathrm{l} \mathrm{L-glutamine,} 1,200 \mathrm{mg} / 1$ sodium bicarbonate, $\mathrm{pH}$ 7.0-7.4. N-acetylcysteine (60 HEPES, 3,151 mg/l, glucose, $55 \mathrm{mg} / 1$ sodium pyruvate, $365 \mathrm{mg} / \mathrm{l} \mathrm{L-Alanine;}$ cat. no. CC-4323; Lonza Bioscience, Inc.), epidermal growth factor (20 ng/ml; cat. no. 11376454001; Roche Diagnostics), human basic fibroblast growth factor $(20 \mathrm{ng} / \mathrm{ml}$; product no. 61977; Cell Signaling Technology, Inc.), leukemic inhibitory factor (10 ng/ml; cat. no. 123-07; ScienCell Research Laboratories, Inc.).

Cell transfection. The STAT5 small interfering (si)RNA (SignalSilence ${ }^{\circledR}$ Stat5 siRNA I; cat. no. 6275) system was obtained from Cell Signaling Biotechnology, Inc. A total of $2 \times 10^{5}$ cells/well primary human pituitary adenoma (HPA) cells were seeded into 6-well culture plates in DMEM/F12 medium. After cells were $\sim 70 \%$ confluent, the primary bromocriptine-resistant human prolactinoma cells were transfected with STAT5 siRNA. Then the cells were treated with $20 \mu \mathrm{M}$ bromocriptine in the presence or absence of $10 \mu \mathrm{M}$ pimozide. The STAT5 siRNA was transfected at a concentration of $100 \mathrm{nM}$ using Lipofectamine ${ }^{\circledR} 3000$ (cat. no. L3000001; Thermo Fisher Scientific, Inc.) transfection reagent per the manufacturer's protocol. Briefly, $25 \mu \mathrm{l}$ of Opti-MEM ${ }^{\mathrm{TM}}$ I medium was mixed with $1.5 \mu \mathrm{l}$ Lipofectamine 3000 reagent in tube 1. Next, $25 \mu 1$ Opti-MEM I medium, 250 ng DNA $(2.5 \mu \mathrm{g} / \mu \mathrm{l})$ and $0.5 \mu \mathrm{l} 3000^{\mathrm{TM}}$ reagent were added and mixed in tube 2 . Tube 2 solution was then added to tube 1 and mixed well. Then, the mixture was incubated at room temperature for $15 \mathrm{~min}$ and $50 \mu \mathrm{l}$ of complex was added to the cells. The plate was gently swirled to ensure homogeneous distribution of the complex to the entire well. Subsequently, $48 \mathrm{~h}$ after transfection, the cells were evaluated for further experiments. After $48 \mathrm{~h}$, the medium was replaced with fresh medium.

Cell proliferation assay. Cell viability was assessed using a Cell Counting Kit-8 (CCK-8; cat. no. AR1199; Wuhan Boster Biotechnology Co., Ltd.) assay. The cytotoxicity of pimozide and/or bromocriptine towards primary human bromocriptine-resistant prolactinoma cells (HPA-BRO) were screened using a CCK- 8 assay. The cells were seeded $\left(1 \times 10^{3}\right.$ cells/well) in 96 -well plates overnight at $37^{\circ} \mathrm{C}$ and then treated with pimozide $(5,10$ and $20 \mu \mathrm{M})$ in the presence or absence of bromocriptine $(5,10$ and $20 \mu \mathrm{M})$ for 2 days. Following stimulation, $10 \mu \mathrm{l}$ CCK- 8 reagent was added to the medium, followed by a 4 -h incubation at $37^{\circ} \mathrm{C}$. The absorption was measured using a microplate reader at $450 \mathrm{~nm}$. The cell viability of each group was calculated relative to the controls, which were normalized to $100 \%$ survival. All analyses were performed in triplicate.

Sphere formation assay. A total of $1 \mathrm{ml}$ cell suspension $\left(1 \times 10^{3}\right.$ cells) was plated per well in triplicate in a 24 -well Corning ultra-low attachment plate in DMEM/F12 medium, supplemented with $10 \mu \mathrm{g} / \mathrm{ml}$ insulin (Sigma-Aldrich; Merck $\mathrm{KGaA}$ ), $1 \mu \mathrm{g} / \mathrm{ml}$ hydrocortisone (Sigma-Aldrich; Merck
KGaA), 1X B27 (Thermo Fisher Scientific, Inc.), $20 \mathrm{ng} / \mathrm{ml}$ EGF, $20 \mathrm{ng} / \mathrm{ml} \mathrm{bFGF}$ and $4 \mu \mathrm{g} / \mathrm{ml}$ heparin (all from Stemcell Technologies, Inc.). After $24 \mathrm{~h}$, the cells were treated with indicated doses of $10 \mu \mathrm{M}$ pimozide, $20 \mu \mathrm{M}$ bromocriptine or combined treatment for 7 days to form primary spheres. Cells were nourished every 3 days through the addition of 50-100 $\mu$ l medium per well. Sphere formation was determined by dividing the total number of spheres by the number of cells plated. For secondary sphere formation assays, primary spheres were dissociated into single cells then replated into new ultra-low attachment 24-well plates for another 7 days. Primary and secondary sphere assays were performed in at least triplicates.

Cell cycle, apoptosis and cell marker analysis. Cells were seeded $\left(1 \times 10^{4}\right.$ cells/plate in complete medium) for $24 \mathrm{~h}$. Subsequently, the cells were treated with $10 \mu \mathrm{M}$ pimozide, $20 \mu \mathrm{M}$ bromocriptine or combined treatment for $24 \mathrm{~h}$. The collected cells were fixed in $70 \%$ ethanol overnight at $-20^{\circ} \mathrm{C}$. Then fixed cells were washed, and incubated in PBS with FxCycle $^{\text {TM }}$ PI/RNase Staining Solution (cat. no. F10797 Invitrogen; Thermo Fisher Scientific, Inc.) with RNase A $(0.5 \mathrm{mg} / \mathrm{ml})$ and propidium iodide (PI; $50 \mu \mathrm{g} / \mathrm{ml})$ for $30 \mathrm{~min}$ at $37^{\circ} \mathrm{C}$. The percentage of cells in each phase of the cell cycle was quantified using a Guava ${ }^{\circledR}$ easyCyte $^{\mathrm{TM}} 8$ flow cytometer (EMD Millipore) with ModFit software 5.0 (Verity Software House). For cell marker analysis, cells were incubated with anti-CD133, anti-nestin or anti-Sox 2 antibodies conjugated to fluorochromes for $30 \mathrm{~min}$ at $37^{\circ} \mathrm{C}$ and analyzed using a flow cytometric system (FACSCalibur; BD Biosciences). Gates were set on the basis of staining with isotype controls (product code ab125938; Abcam) so that no more than $0.1 \%$ of cells were detected with control antibodies. The cells in each group were quantified based on three independent experiments.

Western blot analysis. Cells were collected for lysate preparation. The RIPA Lysis and Extraction Buffer (cat. no. 89901; Thermo Fisher Scientific, Inc.) was used for protein extraction following the manufacturer's protocol. Briefly, cells were washed twice with cold PBS. Cold RIPA Buffer was added to the cells. Then, $1 \mathrm{ml}$ of buffer was used per $75-\mathrm{cm}^{2}$ flask containing cells. This was maintained on ice for $5 \mathrm{~min}$ and the plate was swirled occasionally for uniform spreading. The lysate was gathered to one side using a cell scraper, and then the lysate was collected and transfered to a microcentrifuge tube. The samples were entrifuged at $\sim 14,000 \mathrm{x}$ g for $15 \mathrm{~min}$ to collect the cell debris. The Pierce ${ }^{\mathrm{TM}}$ Rapid Gold BCA Protein Assay Kit (cat. no. A53225; Thermo fisher scientific) was used for protein determination. Briefly, $20 \mu \mathrm{l}$ of each standard sample replicate was pipetted into a microplate well. Then, $200 \mu \mathrm{l}$ of the wash buffer was added to each well and the plate was thoroughly mixed on a plate shaker for $30 \mathrm{sec}$ and subsequently incubated at room temperature for $5 \mathrm{~min}$. The absorbance at or near $480 \mathrm{~nm}$ was measured on a plate reader. Subtracted the average $480 \mathrm{~nm}$ absorbance measurement of the blank standard replicates from the $480 \mathrm{~nm}$ measurements of all other individual standard and unknown sample replicates. A standard curve was prepared by plotting the average blank-corrected $480 \mathrm{~nm}$ measurement for each BSA standard vs. its concentration in $\mu \mathrm{g} / \mathrm{ml}$. The standard curve was used 
to determine the protein concentration of each sample. Equal quantities of protein $(50 \mu \mathrm{g})$ were loaded onto a $10 \%$ SDS gel, resolved using $10 \%$ SDS-PAGE, and transferred to a nitrocellulose membrane for western blot analysis. After blocking the membrane in 5\% milk in TBST for $1 \mathrm{~h}$ at room temperature, the membranes were incubated in diluted primary antibodies $(1: 1,000)$ overnight at $4^{\circ} \mathrm{C}$. Subsequently, the membranes were washed and incubated in HRP-labeled secondary antibodies $(1: 5,000)$ for $1.5 \mathrm{~h}$ at room temperature. SuperSignal West Pico ECL solution (Thermo Fisher Scientific, Inc.) was added to the membranes to enhance the chemiluminescent signal. Protein bands were imaged using a FluorChemE imager (Alpha Innotech). The ImageJ analysis of the western-blot strip grayscale value (band density) was used for relative quantification. Average pixel intensity was obtained after image inversion from black to white pixels using the freeware ImageJ from the National Institutes of Health.

Animals and treatments. For the tumor grafting experiments, primary cells obtained from human prolactinoma tissues were cultured in complete DMEM/F12 and harvested during the logarithmic phase of growth. After adjusting the cell number based on viability, $1 \times 10^{6}$ viable cells were subcutaneously injected into the flank of nude mice. A total number of 16 ( 8 male, 8 female) nude mice were used in our study. Upon arrival, at 6 weeks of age, animals were weighed (18-20 grams), ear tagged, and split into 4 different groups $(n=4)$ following a stratified randomization scheme in order for all groups to have a similar body weight distribution at the beginning. All mice were housed in same-sex groups of 5, in type II polycarbonate cages in individually ventilated caging systems with bedding and water and food ad libitum with a standardized NIH-31 diet (cat. no. LAD-NIH-31 diet; TROPHIC Animal Feed High-tech Co., Ltd.). Cages were cleaned every week. On those occasions, mice were also weighed and examined to evaluate their health. The animal room had a controlled 12-h light/dark cycle (lights on at 6:00 $\mathrm{AM})$, temperature $\left(22 \pm 2^{\circ} \mathrm{C}\right)$, and relative humidity (45-65\%). Food intake was measured by weighing uneaten pellets. Pimozide (200 $\mu \mathrm{g} / \mathrm{mouse})$, bromocriptine $(20 \mathrm{mg} / \mathrm{kg})$ or combined treatment was administered via an intraperitoneal injection into mice in the treatment group for 24 days. Injections were performed from the 6th day after the initial intraperitoneal injection until the 30th day. Tumor volumes were measured every other day. The tumor volume was calculated as follows: Tumor volume=longest diameter $\mathrm{x}$ shortest diameter ${ }^{2}$ x 0.5 . Tumor grafts were removed and processed for further analysis. All procedures involving mice were approved by the HUST Institutional Animal Care and Use Committee and performed in accordance with the National Institutes of Health Guide for the Care and Use of Laboratory Animals, 8th edition, 2011.

Immunohistochemical staining. Tumor specimens were derived from formalin-fixed, paraffin-embedded tissue samples. Following antigen retrieval and blocking, tumor tissues were incubated with Ki67 (diluted 1:100) and p-STAT5 (diluted 1:50) antibodies overnight at $4^{\circ} \mathrm{C}$. The slides were then incubated with biotinylated anti-rabbit IgG secondary antibody (cat. no. PK-7200; 1:1,000 dilution;Vectastain Elite ABC-HRP Kit; Vector Laboratories, Inc.) for $30 \mathrm{~min}$ at room temperature, followed by incubation in Vectastain Elite ABC Reagent for $30 \mathrm{~min}$ at room temperature. For all slides, a diaminobenzidine detection kit (Vector Laboratories, Inc.) was used according to the manufacturer's protocol. The sections were then counterstained with Meyer's hematoxylin for $8 \mathrm{~min}$ at $37^{\circ} \mathrm{C}$, dehydrated, and mounted. Slides were observed and imaged using a light Nikon ECLIPSE E100 microscope at a magnification of $\mathrm{x} 40$ or $\mathrm{x} 100$.

Statistical analysis. Statistical analysis was performed using GraphPad Prism 5 (GraphPad Software, Inc.). A Duncan's test was used to assess differences between multiple groups using one-way ANOVA. A unpaired t-test was used to compare the means of two groups. Data are presented as the mean \pm SD. $\mathrm{P}<0.05$ was considered to indicate a statistically significant difference.

\section{Results}

Basal activation of PRL/JAK2/STAT5 signaling in bromocriptine-resistant tumor cells. The role of PRL/JAK2/STAT5 signaling in bromocriptine-resistant prolactinoma has not been explored, to the best of our knowledge. To address this issue, PRL/JAK2/STAT5 signaling was assessed using immunohistochemistry in 8 bromocriptine-resistant and 8 bromocriptine-sensitive prolactinoma specimens. Although not all the differences were statistically significant, drug-resistant samples exhibited higher basal levels of p-JAK2, p-STAT5 and PRLR protein expression (Fig. 1). For further investigation, MMQ cells were used to establish bromocriptine-resistant cells (MMQ/BRO). As described in a previous study (5), the bromocriptine-resistant cells were treated for 6 months with increasing concentrations of bromocriptine. In line with this previous study (5), the MMQ/BRO cells expressed higher basal levels of p-JAK2, p-STAT5 and PRLR in comparison with their parental MMQ cells (Fig. 1). Collectively, these data indicated that PRL/JAK2/STAT5 signaling was activated in bromocriptine-resistant tumor cells, which may contribute to bromocriptine resistance in prolactinomas.

Pimozide enhances bromocriptine-induced cytotoxicity in prolactinoma cells. Given that pimozide acts as an inhibitor of STAT5 (22), a CCK-8 assay was used to determine whether pimozide sensitized prolactinoma cells to bromocriptine chemotherapy. The dose was initially optimized for combined treatment. CCK-8 assay revealed that $5 \mu \mathrm{M}$ pimozide or $5 \mu \mathrm{M}$ bromocriptine treatment for $48 \mathrm{~h}$ did not result in any significant cytotoxic effects in HPA-BRO cells. A combined treatment of $10 \mu \mathrm{M}$ pimozide and $20 \mu \mathrm{M}$ bromocriptine significantly reduced cell viability to $52.81 \pm 4.13 \%$ compared with $5 \mu \mathrm{M}$ pimozide plus $20 \mu \mathrm{M}$ bromocriptine treatment (Fig. 1D and E). Collectively, these data indicated a strong synergism between the toxicity of pimozide and bromocriptine treatment in primary human bromocriptine-resistant prolactinoma cells.

Pimozide enhances bromocriptine-induced anti-stemness efficiency in prolactinoma cells. Given that tumor stem cells have been suggested to be responsible for drug resistance (5), whether pimozide and bromocriptine combined treatment 


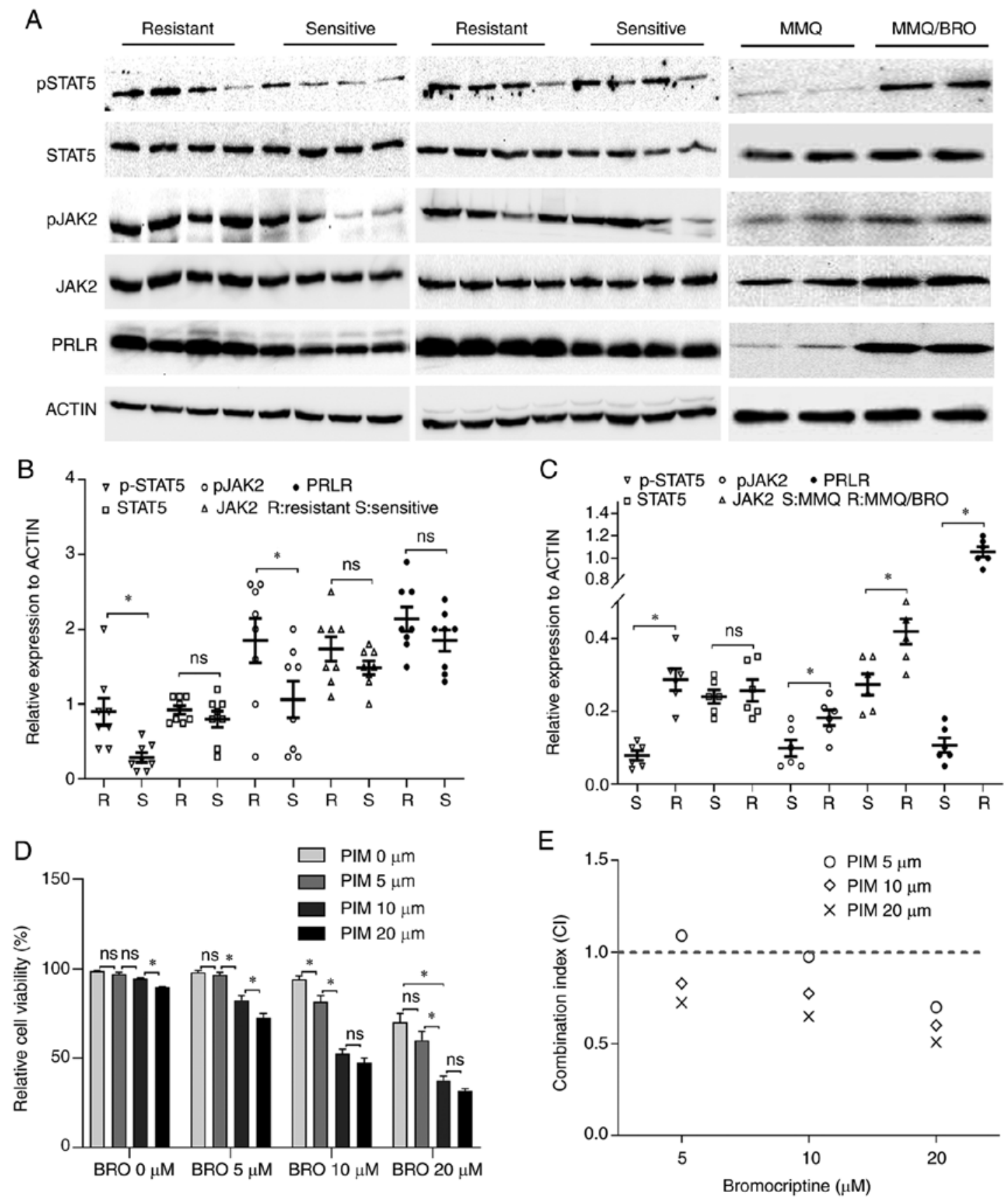

Figure 1. Increased p-STAT, p-JAK2 and PRLR expression in bromocriptine-resistant prolactinoma tissues and MMQ cells. (A) Western blots of p-STAT5, STAT5, p-JAK2, JAK2 and PRLR protein levels in bromocriptine-resistant and -sensitive prolactinoma tissues and MMQ cells. (B) Scatter plots of p-STAT5, STAT5, p-JAK2, JAK2 and PRLR protein levels in 8 bromocriptine-sensitive (Sensitive) and 8 bromocriptine-resistant (Resistant) prolactinoma tissues. Data are presented as the mean \pm SD (Student's t-test; ${ }^{*} \mathrm{P}<0.05$ ). (C) Scatter plots of p-STAT5, STAT5, p-JAK2, JAK2 and PRLR protein levels in bromocriptine-sensitive (S) and bromocriptine-resistant (R) MMQ cells. Data are presented as the mean \pm SD (Student's t-test; "P<0.05). (D) Pimozide enhanced inhibition of MMQ/BRO cell proliferation mediated by bromocriptine. MMQ/BRO cells were treated with bromocriptine $(5,10$ and $20 \mu \mathrm{M})$ in the presence of pimozide $(5,10$ and $20 \mu \mathrm{M})$ for three days. Cell viability was measured using a CCK-8 assay. Results are presented as the mean \pm standard error of the mean; ${ }^{*} \mathrm{P}<0.05$. (E) CI of bromocriptine and pimozide based on the CCK-8 assays. Pimozide synergistically enhanced bromocriptine-induced growth inhibition, as indicated by a $\mathrm{CI}<1$. p-, phospho; PRLR, prolactin receptor; CI, combination index; CCK-8, Cell Counting Kit-8; CON, control; BRO, bromocriptine; PIM, pimozide; ns, not significant;

affected prolactinoma cell stemness was determined. As revealed in our previous study (20), the $\mathrm{CD}_{133^{+}}$nestin $^{+}$ stem-like MMQ cells were isolated using CD133 and nestin magnetic micro beads (Fig. 2A and B). Since Sox 2 is known as a marker for pituitary adenoma stem cells (23), after isolation, the purity of CD133-, nestin- and Sox2-positive cells was also examined by flow cytometry. The proportion of CD133-, nestin- and Sox2-positive cells was 69.31, 61.58 and $30.64 \%$, respectively (Fig. 2C). Although there were only $30.64 \%$ Sox 2-positive cells, the proportion was significantly higher than $1.71 \%$ of parental MMQ cells (data not shown). As revealed in Fig. 2A, the isolated cells also displayed sphere-forming capacity in the present study. All these data supported to some extent the existence of stemness in the isolated $\mathrm{CD}_{133^{+}}$nestin $^{+}$stem-like MMQ cells. Since the sphere formation assay is the gold standard assay to assess 
A

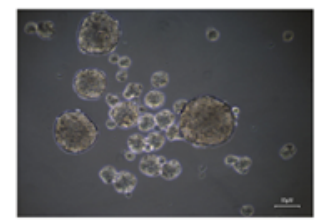

Control

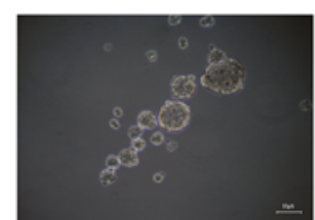

Bromocriptine

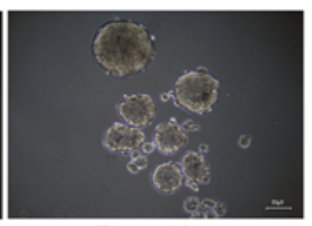

Pimozide

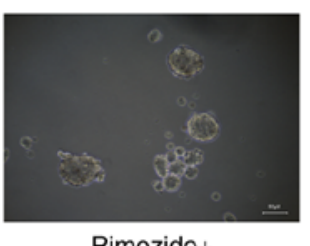

Pimozide+

Bromocriptine
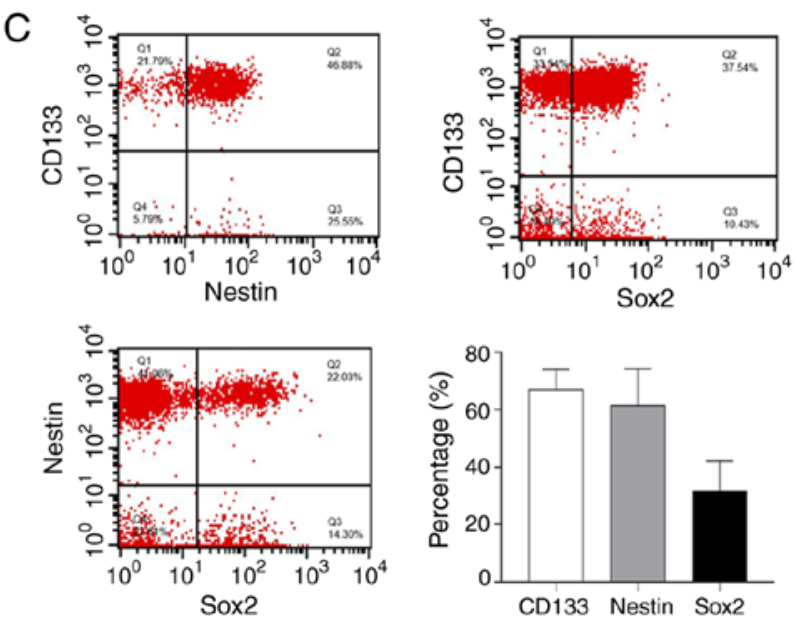

E

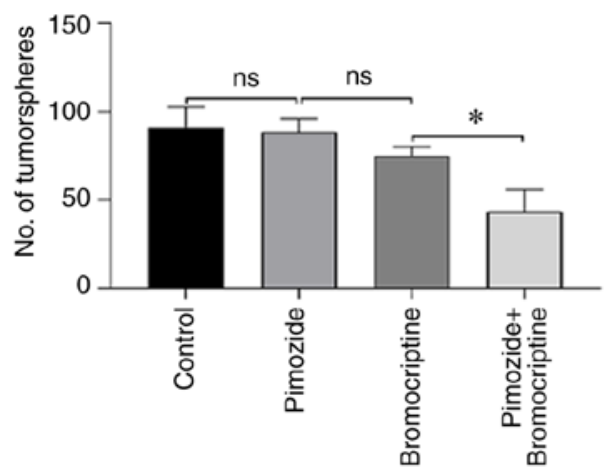

B

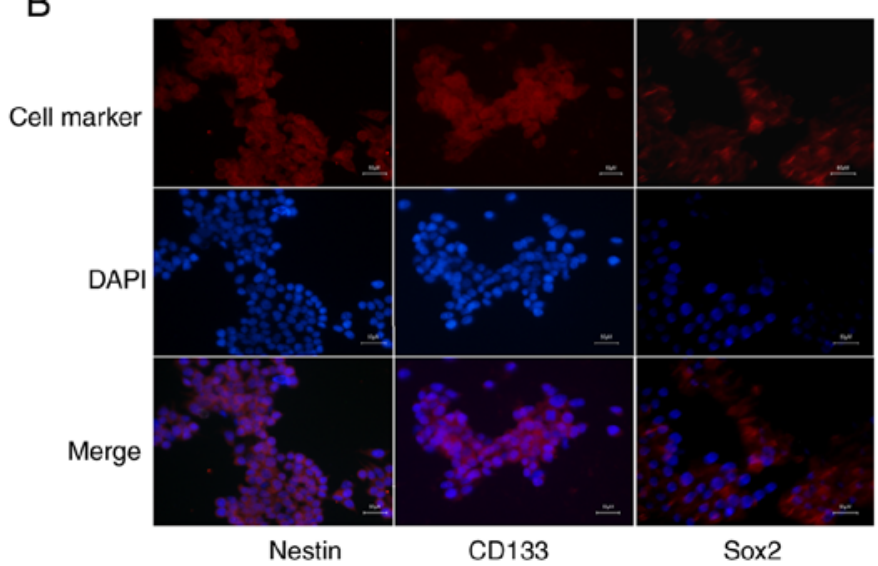

D

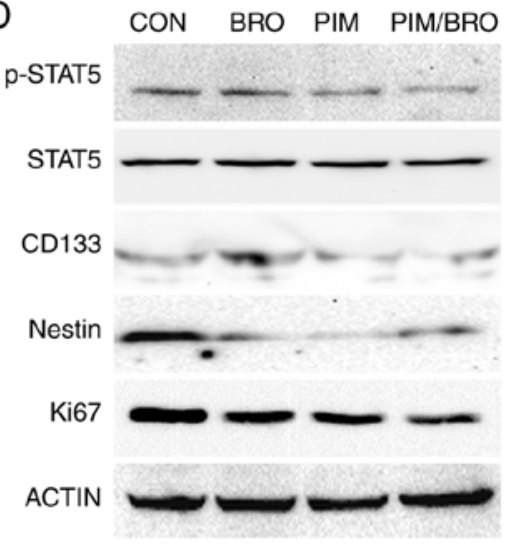

\section{F}

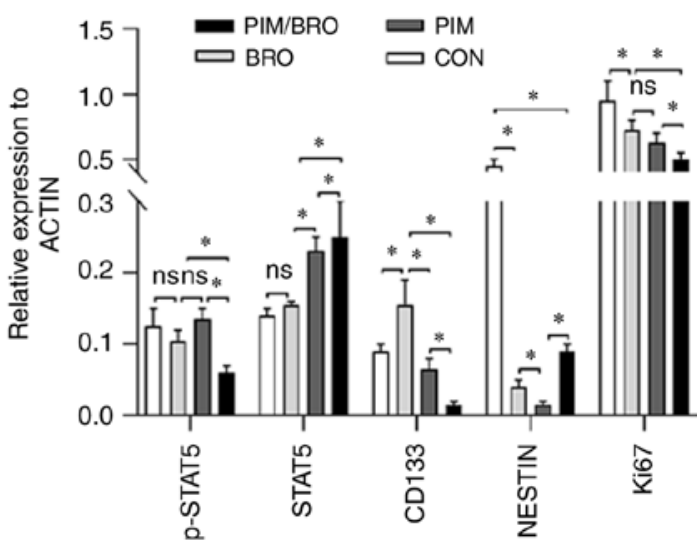

Figure 2. (A) Representative images of the tumorsphere formation assay of CD133+ nestin ${ }^{+}$stem-like MMQ cells. Scale bar represents $50 \mu$ m. (B) Immunofluorescence analysis of CD133, nestin or Sox 2 (red) and DAPI (blue) in CD133 ${ }^{+}$nestin ${ }^{+}$stem-like MMQ cells (magnification, $\mathrm{x} 10$ ). Scale bar represents $50 \mu \mathrm{m}$. (C) The representative cytometric dot-plots of nestin, CD133 and Sox 2 expression in CD133 ${ }^{+}$nestin ${ }^{+}$stem-like MMQ cells. (D) Representative western blots of p-STAT5, STAT5, CD133, nestin and Ki67 protein expression in CD133 ${ }^{+}$nestin ${ }^{+}$stem-like MMQ cells treated with vehicle control, $10 \mu$ M pimozide, $20 \mu \mathrm{M}$ bromocriptine or both drugs combined. Pimozide in combination with bromocriptine suppressed the expression of the tumor stem cell marker proteins CD133 and nestin, compared with either drug alone. Results are presented as the mean \pm standard error of the mean. (E) Quantitative results of the $\mathrm{CD}_{133^{+}}$nestin ${ }^{+}$stem-like MMQ cell tumorsphere formation assay treated with vehicle control, $10 \mu \mathrm{M}$ Pimozide, $20 \mu \mathrm{M}$ bromocriptine or both drugs combined for 7 days. The combination treatment suppressed the formation of tumorspheres and growth of the CD133 ${ }^{+}$nestin ${ }^{+}$stem-like MMQ cells, compared with bromocriptine alone. Results are presented as the mean \pm standard error of the mean. * P $<0.05$. (F) Quantification of p-STAT5, STAT5, CD133, nestin and Ki67 protein levels in $\mathrm{CD}_{133^{+}}$nestin ${ }^{+}$stem-like MMQ cells treated with vehicle control, $10 \mu \mathrm{M}$ pimozide, $20 \mu \mathrm{M}$ bromocriptine or both drugs combined. Data are presented as the mean \pm SD (Student's t-test; ${ }^{\mathrm{P}}<0.05$ ). p-, phospho-; CON, control; BRO, bromocriptine; PIM, pimozide; STAT5, signal transducer and activator of transcription 5A; Sox2, SRY-box transcription factor 2; ns, not significant.

the stemness of cells (24), the effect of the pimozide and bromocriptine combined treatment on the stemness of CD133+ nestin ${ }^{+}$pituitary adenoma stem-like cells was assessed using the sphere formation assay. Because in the aforementioned
CCK-8 assay it was revealed that the concentration of pimozide $(10 \mu \mathrm{M})$ and bromocriptine $(20 \mu \mathrm{M})$ was the minimum dose required to achieve the maximum synthetic lethal effect in vitro, we employed pimozide $(10 \mu \mathrm{M})$ and bromocriptine 
A

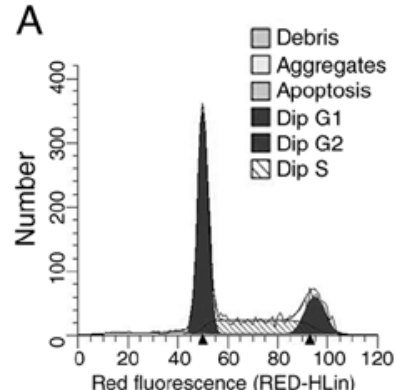

CON

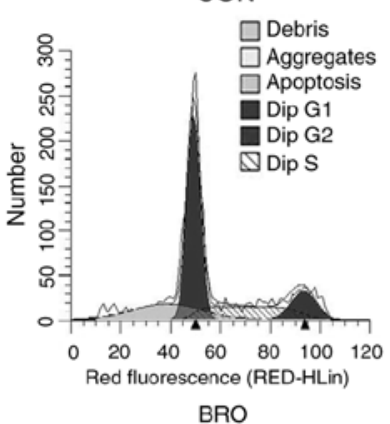

BRO

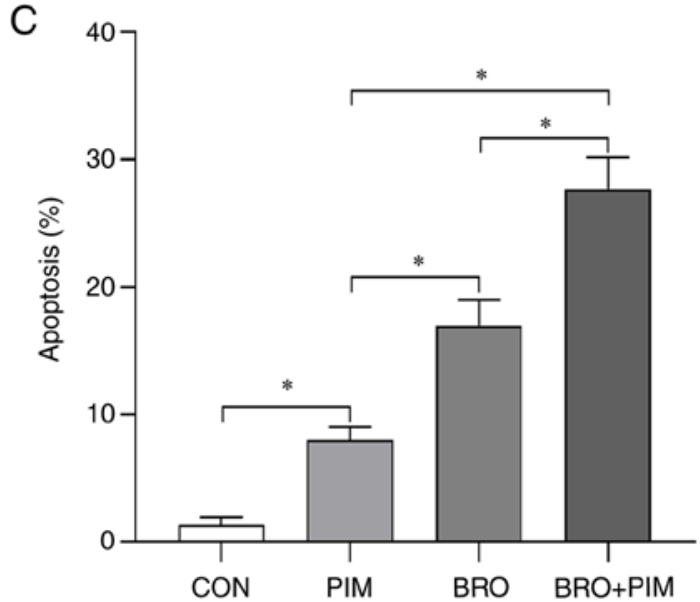

$\mathrm{B}$

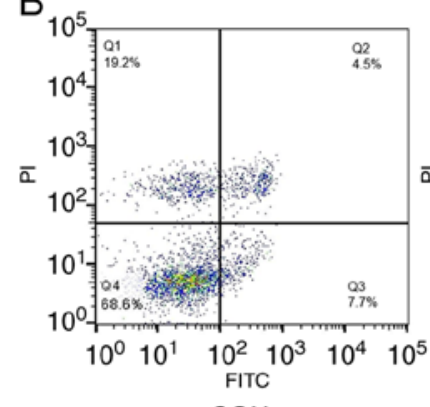

CON
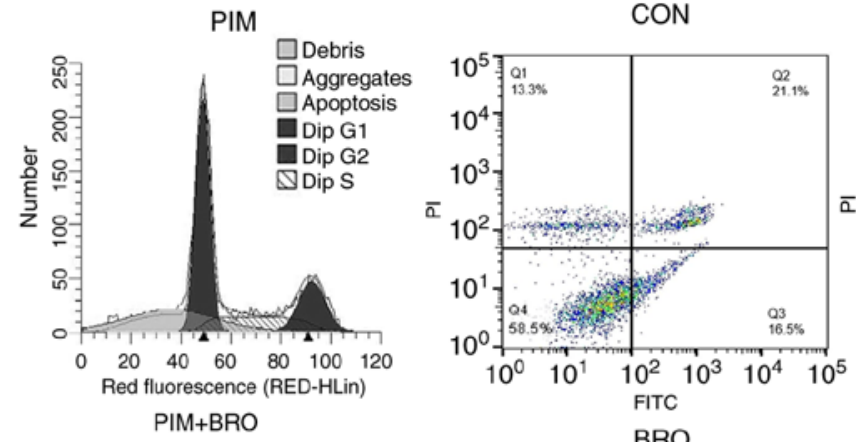

BRO

D

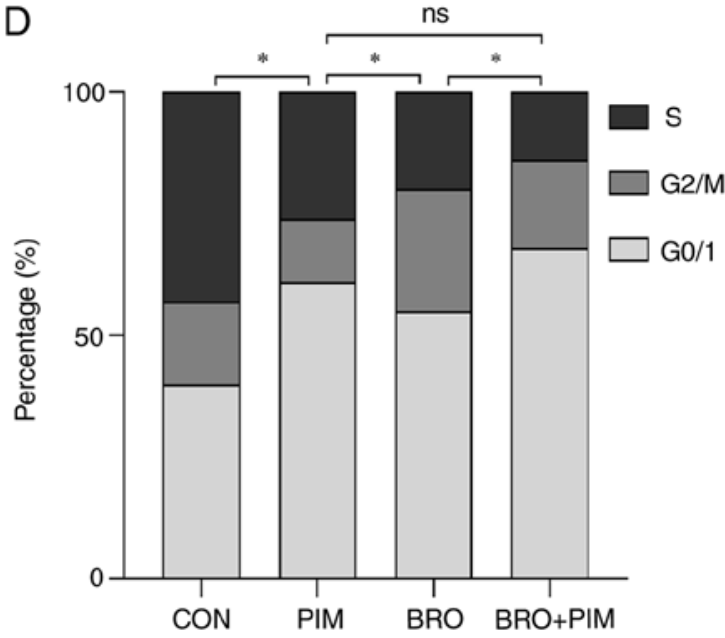

Figure 3. (A) Representative flow cytometric images of cell cycle distribution in MMQ/BRO cells treated with $20 \mu \mathrm{M}$ bromocriptine and/or $10 \mu \mathrm{M}$ pimozide for $24 \mathrm{~h}$. Both bromocriptine or pimozide alone induced apoptosis, G0/G1 arrest, and bromocriptine-induced growth inhibition was significantly sensitized in cells treated with both bromocriptine and pimozide. One-way ANOVA analysis. (B) Flow cytometric apoptosis analysis in MMQ/BRO cells treated with $20 \mu \mathrm{M}$ bromocriptine and/or $10 \mu \mathrm{M}$ pimozide for $24 \mathrm{~h}$. Both bromocriptine or pimozide alone induced apoptosis, and increased apoptosis was found in $\mathrm{MMQ} / \mathrm{BRO}$ cells treated by bromocriptine plus pimozide. (C) Quantification of the percentage of apoptosis in MMQ/BRO cells determined by flow cytometric analysis. (D) Quantification of the percentage of G0/1, G2/M and S cells in MMQ/BRO cells determined by flow cytometric analysis. Results are presented as the mean \pm standard error of the mean. ${ }^{\mathrm{P}}<0.05$. CON, control; BRO, bromocriptine; PIM, pimozide.

$(20 \mu \mathrm{M})$ for the experiment. The results revealed that 7 days of pimozide and bromocriptine combined treatment significantly reduced tumor sphere formation in the $\mathrm{CD} 133^{+}$nestin ${ }^{+}$ pituitary adenoma stem-like cells compared with either drug alone (Fig. 2A and E). Furthermore, the combined treatment reduced the expression of CD133 levels in the tumor spheres of $\mathrm{CD}_{133^{+}}$nestin $^{+}$pituitary adenoma stem-like cells compared to the pimozide or bromocriptine monotherapy (Fig. 2D and F). These data indicated that pimozide sensitized prolactinoma cells to bromocriptine chemotherapy through inhibition of cell growth and stemness.

Pimozide enhances bromocriptine-induced cell cycle arrest and apoptosis in MMQ-BRO cells. To identify the cellular mechanisms underlying the chemosensitizing effects of pimozide on bromocriptine treatment, the apoptosis rates and cell cycle distribution were analyzed in prolactinoma cells. As there is always a small proportion of fibroblast cells mixed with HPA cells after long term culture, the heterogeneity of the primary cultured HPA cells may undermine the reliability of proliferation and signaling research (25). In the present study, MMQ/BRO cells were used for cell cycle and apoptosis analysis (Fig. 3A and B). Although the ratio was relatively low, flow cytometric analysis revealed increased apoptosis in MMQ-BRO+PIM (28.34 $\pm 2.83 \%)$ cells following $24 \mathrm{~h}$ of the combined treatment compared with either pimozide $(8.84 \pm 2.15 \%)$ or bromocriptine alone (17.81 $\pm 1.10 \%)$ (Fig. 3C). In terms of cell cycle distribution, $24 \mathrm{~h}$ of the combined treatment resulted in cell cycle arrest at the G0/1 stage $(68.82 \pm 4.15 \%)$, compared with either pimozide $(60.87 \pm 3.16 \%)$ 


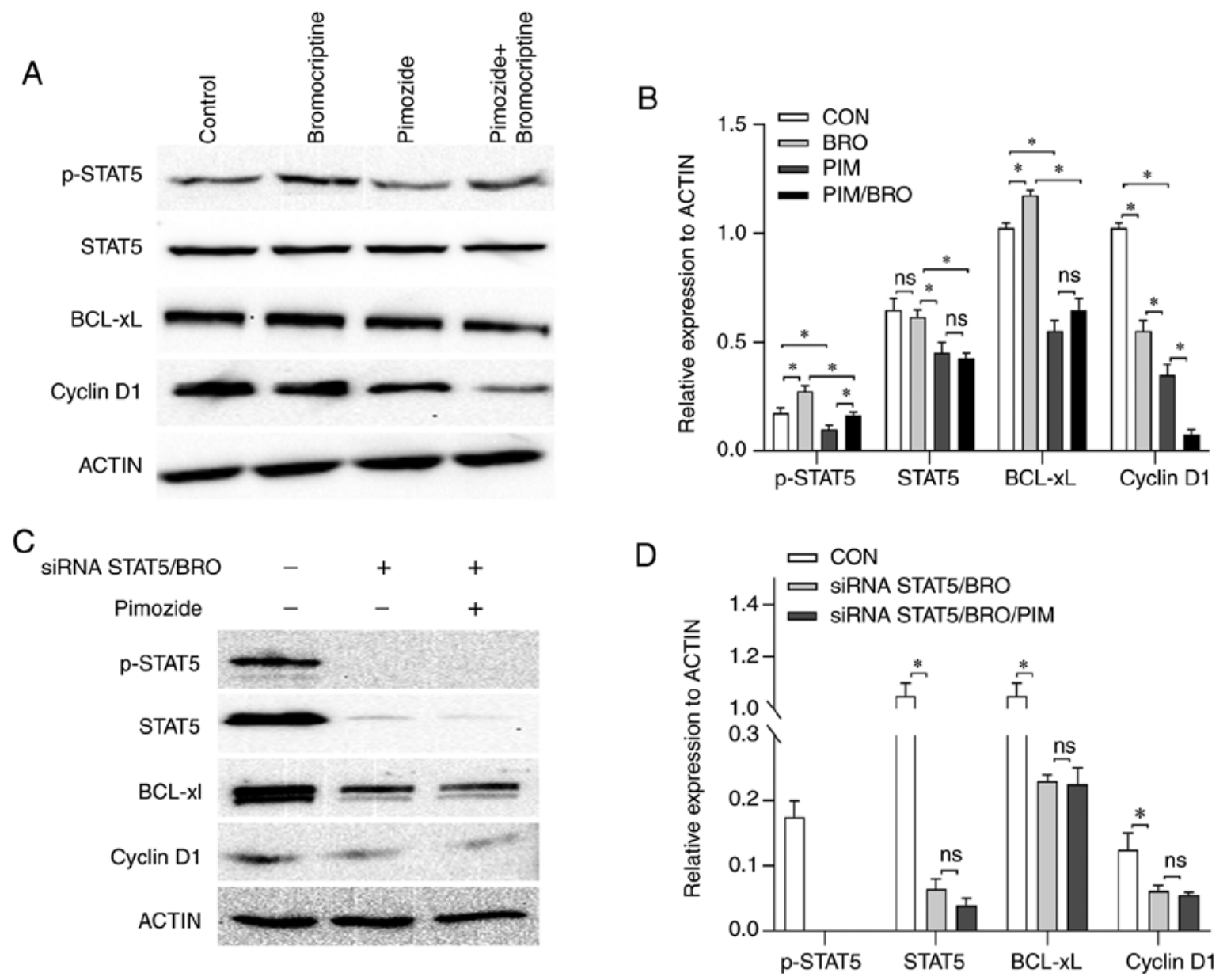

Figure 4. (A) Representative western blot images and (B) quantification of p-STAT5, STAT5, Bcl-xL and cyclin D1 protein expression levels in MMQ/BRO cells treated with vehicle control, $10 \mu \mathrm{M}$ pimozide, $20 \mu \mathrm{M}$ bromocriptine or both drugs combined for $24 \mathrm{~h}$. Pimozide abrogated the bromocriptine-induced p-STAT5 and Bcl-xL upregulation for $24 \mathrm{~h}$. (C) Representative western blots and (D) quantification of p-STAT5, STAT5, Bcl-xL and cyclin D1 protein expression levels in STAT5-knockdown primary bromocriptine-resistant human prolactinoma cells treated with $20 \mu \mathrm{M}$ bromocriptine in the presence or absence of $10 \mu \mathrm{M}$ pimozide for $24 \mathrm{~h}$. Data are presented as the mean $\pm \mathrm{SD}$ (Student's t-test; ${ }^{*} \mathrm{P}<0.05$ ). Compared with bromocriptine treatment alone, the combination of pimozide with bromocriptine did not exert any notable additional antiproliferative effects in siRNA STAT5/BRO cells. p-, phospho-; STAT5, signal transducer and activator of transcription 5A; Bcl-xL, B-cell lymphoma extra-large; si, small interfering; CON, control; BRO, bromocriptine; PIM, pimozide.

or bromocriptine alone $(51.92 \pm 5.12 \%)$ (Fig. 3D). These results indicated that pimozide sensitized prolactinoma cells to bromocriptine chemotherapy by inducing cell cycle arrest and apoptosis.

Pimozide augments the cytotoxicity of bromocriptine via inhibition of STAT5/Bcl-xL and STAT5/cyclin D1 signaling. The molecular mechanisms underlying the pimozide-induced augmented antitumor effects to bromocriptine treatment were assessed. As the heterogeneous nature of the primary HPA cells may have undermined the reliability of the molecular mechanism research, the effect of pimozide on the expression of apoptosis and cell cycle signaling-related regulators, including anti-apoptotic proteins $\mathrm{Bcl}-\mathrm{xL}$ and cell cycle regulator (cyclin D1) expression in $\mathrm{MMQ} / \mathrm{BRO}$ cells was assessed. Treatment with $10 \mu \mathrm{M}$ pimozide for $24 \mathrm{~h}$ decreased p-STAT5, $\mathrm{Bcl}-\mathrm{xL}$ and cyclin D1 expression levels compared to the control. Bromocriptine at $20 \mu \mathrm{M}$ for $24 \mathrm{~h}$ resulted in higher p-STAT5 and Bcl-xL but lower cyclin D1 expression levels compared to the control. Furthermore, the combined treatment with pimozide abrogated the bromocriptine-induced p-STAT5 and Bcl-xL upregulation (Fig. 4A and B).
As pimozide is an inhibitor of STAT5 (22), the role of STAT5 on cell proliferation signaling in primary culture bromocriptine-resistant prolactinoma cells was assessed. A STAT5 siRNA was used to knockdown STAT5. STAT5 knockdown decreased cyclin D1 and Bcl-xL expression compared to the control (Fig. 4C and D). Additionally, STAT5 knockdown significantly increased bromocriptine cytotoxicity in primary culture prolactinoma cells. Furthermore, compared with bromocriptine treatment alone, pimozide in combination with bromocriptine did not exert any notable additional antiproliferative effects in STAT5-knockdown cells (data not shown). These results indicated that STAT5/cyclin D1 and STAT5/Bcl-xL contributed to the acquired antitumor effects induced by pimozide in combination with bromocriptine.

Pimozide synergizes with bromocriptine in suppressing tumor growth, STAT5 signaling and stem cell marker expression in human prolactinoma xenograft tissues. To investigate the in vivo therapeutic effects of pimozide-bromocriptine combination, the effect of the combined treatment on subcutaneous growth of human bromocriptine-resistant prolactinoma tissue xenografts was assessed. As described in our previous 

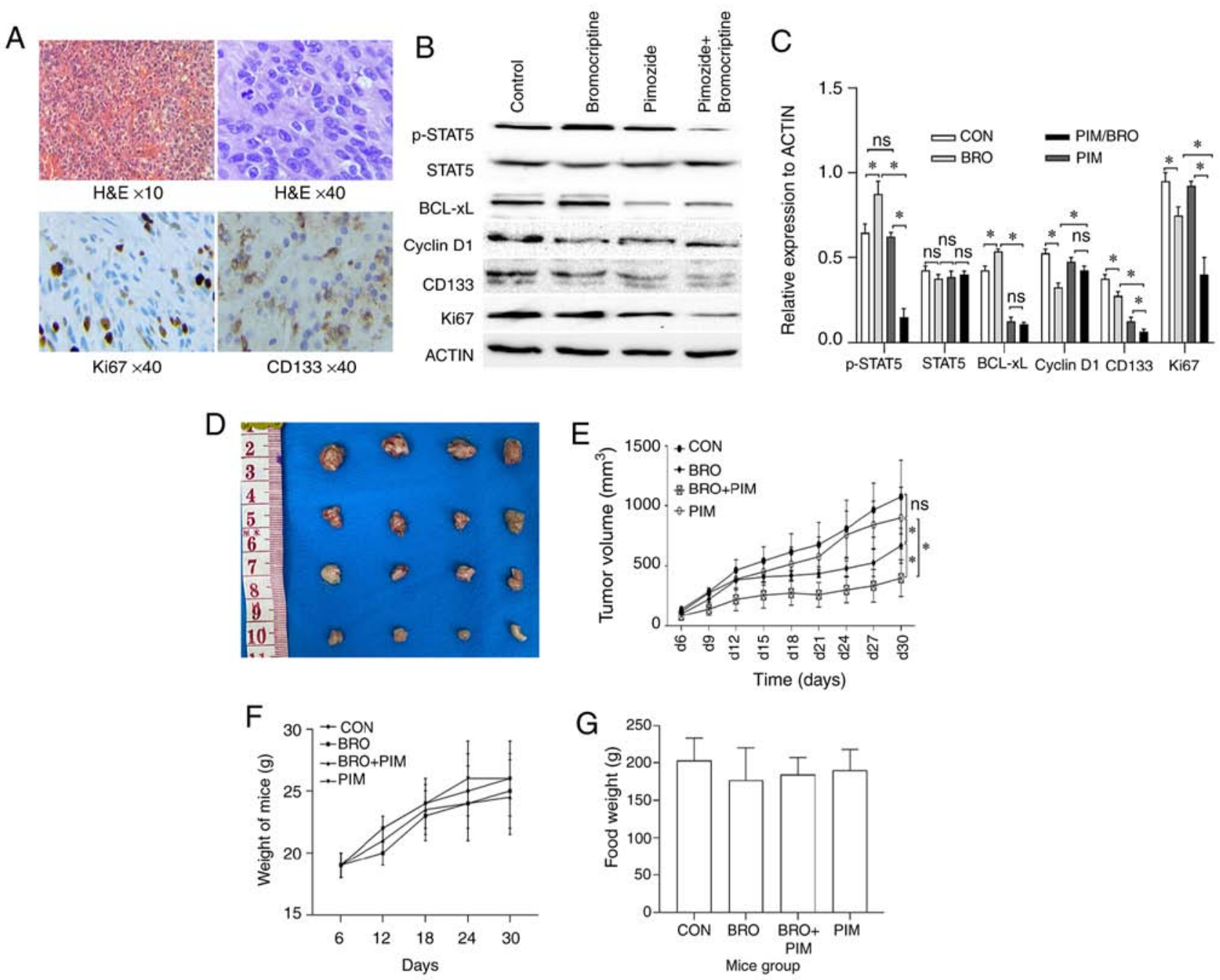

Figure 5. (A) Representative images of H\&E and immunohistochemistry staining of CD133 and Ki67 in human prolactinoma tissue xenograft tumors (magnification, x40). Decreased CD133 and Ki67 protein expression levels were observed in the bromocriptine/pimozide group tumors. (B) Representative western blot images and (C) quantification of p-STAT5, STAT5, Bcl-xL, cyclin D1, CD133 and Ki67 protein expression levels in human prolactinoma tissue xenografts. Pimozide in combination with bromocriptine suppressed the expression of tumor stem cell marker proteins CD133, compared with either drug alone. (D) and (E) Synergistic inhibitory effect of bromocriptine and pimozide on tumor growth in nude mice. Human prolactinoma tissue xenograft mice were treated daily with $20 \mathrm{mg} / \mathrm{kg}$ bromocriptine in the absence or presence of $200 \mu \mathrm{g} /$ mouse pimozide every three days (n=3 per group). Pimozide combined with bromocriptine significantly suppressed xenograft growth. Tumor volumes were measured using calipers every other day. The tumor volume was calculated as follows: $0.5 \mathrm{x}$ length $\mathrm{x}$ width ${ }^{2}$. Results are presented as the mean \pm standard error of the mean. ${ }^{*} \mathrm{P}<0.05$. (F) Body weight change and $(\mathrm{G})$ food intake in mice during the experimental period. Data are presented as the mean $\pm \mathrm{SD}$. Statistical significance was calculated using t-test. H\&E, hematoxylin and eosin; p-, phospho-; STAT5, signal transducer and activator of transcription 5A; Bcl-xL, B-cell lymphoma extra-large; si, small interfering; CON, control; BRO, bromocriptine; PIM, pimozide; ns, not significant.

study (21), human prolactinoma tissue was subcutaneously injected into nude mice. After palpable tumors had formed, the mice were randomized into four groups receiving control, pimozide and bromocriptine alone, or a combined treatment. The tumorigenesis assay demonstrated that the antitumor effects of the drug combination were significantly greater than either agent alone (Fig. 5D and E). H\&E images of xenografts displayed monomorphic giant cells with granular cytoplasm, round nuclei with finely dispersed chromatin and multiple distinct nucleoli. KI67 nuclear and CD133 cytoplasmic staining was also confirmed (Fig. 5A). Moreover, toxicity of drugs was evaluated based on the food intake and weight of the mice (Fig. 5F and G). The body weight gain and total food intake in all groups was similar at the end of the experiment. These data indicated that drug administration had no severe effects.
The effect of pimozide on the expression of STAT5/cyclin D1 and STAT5/Bcl-xL signaling in vivo was also assessed. Western blotting revealed that pimozide treatment in xenograft mice significantly reduced p-STAT5, CD133 and Ki67 protein expression levels in tumors receiving the combined treatment compared with the pimozide monotherapy controls. Unexpectedly, cyclin D1 and Bcl-xL expression slightly decreased, but the difference was not statistically significant (Fig. 5B and C). Collectively, these data indicated that pimozide may have the potential to serve as a chemosensitizer to bromocriptine in bromocriptine-resistant cells in vivo.

\section{Discussion}

In the present study, increased expression of p-JAK2 and p-STAT5 was observed in bromocriptine-resistant 


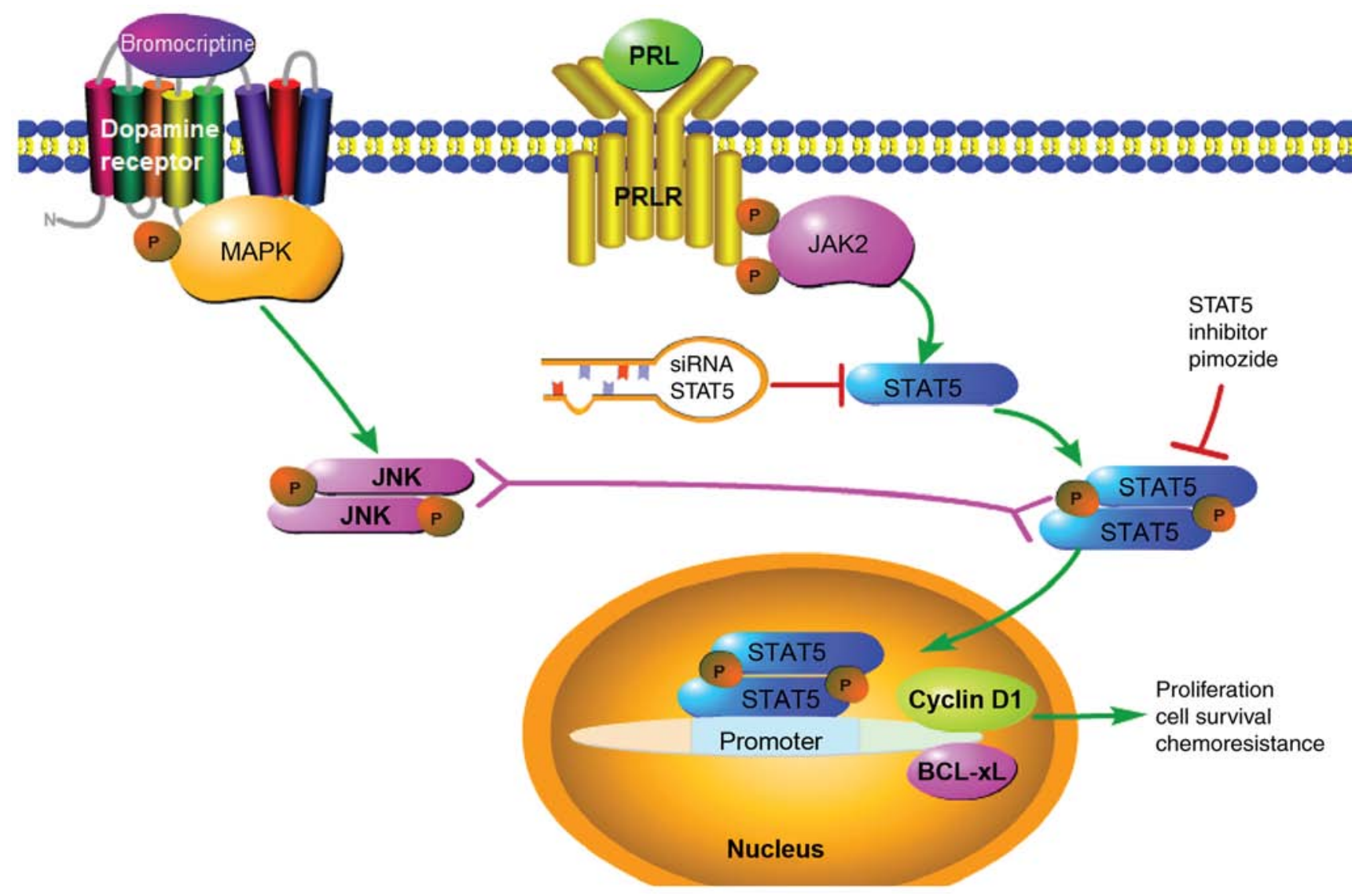

Figure 6. Proposed mechanism of pimozide in prolactinoma bromocriptine resistance. Pimozide inhibits the expression of STAT5, which suppresses cyclin D1 and Bcl-xL, resulting in reversal of bromocriptine resistance. PRL contributes to drug resistance through activation of the JAK2/STAT5 signaling pathway. Bromocriptine treatment alone increased STAT5 and Bcl-xL activation, and reduced cyclin D1 activity in prolactinoma cells. When combined with bromocriptine, pimozide suppressed activation of STAT5, which further decreased cyclin D1 and Bcl-xL expression. Further mechanistic studies are required for detailed characterization. The solid arrow represents a promoting effect, the red $\mathrm{T}$ symbol represents an inhibitory effect and the double headed arrow represents possible crosstalk between signaling. PRL, prolactin; PRLR, prolactin receptor; STAT5, signal transducer and activator of transcription 5A; Bcl-xL, B-cell lymphoma extra-large.

prolactinoma tissues and cells. In our clinical practice, patients with bromocriptine-resistant prolactinoma usually suffer from hyperprolactinemia (26-28). Increased serum levels of PRL tend to bind PRLR forming a complex, and further activate the classical PRL/JAK2/STAT5 pathways $(8,29,30)$. Previous studies have also revealed that STAT5 has several target genes, among which, cell cycle regulator cyclin D1 is a STAT5 target gene. STAT5 can bind at -481 bp of the cyclin D1 promoter and promote cell cycle progression (31-34). In addition, STAT5-deficient mice were revealed to exhibit decreased Bcl-xL expression which resulted in the suppression of cell growth $(35,36)$. As hyperactivated STAT5 leads to the aberrant expression of its target genes including antiapoptotic, proliferative and pro-inflammatory genes, which promote tumorigenesis $(33,37)$, it was hypothesized that activated STAT5/cyclin D1 and STAT5/Bcl-xL signaling may contribute to the bromocriptine resistance in prolactinomas.

In the present study, $10 \mu \mathrm{M}$ pimozide alone did not exhibit any notable antitumor efficacy in bromocriptine-resistant cells. However, a supra-additive effect on growth inhibition was observed when pimozide was combined with bromocriptine. Pimozide combined with bromocriptine treatment induced apoptosis and $\mathrm{G}_{0} / \mathrm{G}_{1}$ cycle arrest in bromocriptine-resistant cells. Furthermore, selective siRNA-mediated STAT5 inhibition reduced the viability of cells and downregulated the expression of Bcl-xL and cyclin D1. Pimozide combined with bromocriptine did not exert any notable additional antiproliferative effects in STAT5-siRNA primary culture human prolactinoma cells. Mechanistically, pimozide was effective in inhibiting STAT5 and its downstream effectors, cyclin D1 and Bcl-xL. Since cyclin D1 is a modulator of the cell cycle and $\mathrm{Bcl}-\mathrm{xL}$ affects apoptosis $(9,38,39)$, it was proposed that STAT5/cyclin D1 and STAT5/Bcl-xL may contribute to the antitumor effects of pimozide.

Bromocriptine regulates several signaling pathways in tumorigenesis and progression, including the PI3K/AKT and the MAPK/JNK/ERK signaling pathways $(4,40)$. Previous studies have also revealed that STAT proteins are important downstream targets of MAPK and JAK signaling (19,41-43). Although the exact mechanism is not completely understood, it has been hypothesized that there may be crosstalk between the STAT5 and JNK/MAPK pathways. In the present study, bromocriptine alone resulted in upregulation of p-STAT5 and Bcl-xL expression, and downregulation of cyclin D1 expression compared to the control. Pimozide treatment decreased Bcl-xL expression, but had no obvious effect on p-STAT5 expresion compared to the control. When pimozide was combined with bromocriptine, the expression of p-STAT5 and Bcl-xL was further decreased compared to bromocriptine monotherapy. This opposing p-STAT5 regulation may be due to the several 
roles of JNK in STAT5 modulation and the crosstalk between JNK/STAT5 and JAK2/STAT5 in different types and statuses of studied cells. In the present study, no statistical difference was observed in the baseline STAT5 expression between the bromocriptine-resistant and sensitive human prolactinoma tissues. The are two possible reasons for this unexpected result. The first is that the total amount of STAT5 may be affected by a variety of pathophysiological factors in vivo, thus there may be no statistical difference in the total amount. Second, the overall sample size of this study was relatively small, and more patient samples are required for further study. Nevertheless, understanding the crosstalk between JNK/MAPK, JAK2 and STAT5 will be helpful to illustrate the heterogeneity that exists between different types of cancer.

The combined therapy may have possibly increased toxicity. Both JNK/MAPK and JAK signaling pathways exert important roles in human cell physiology $(37,44)$. Undesirable consequences may be encountered upon simultaneous inhibition of both pathways. In the present study, no noticeable side effects were observed in the mice. The combination of bromocriptine and pimozide was found to yield improved antitumor activity compared with either drug alone. These data suggest that the dual inhibition strategy was effective in patients with bromocriptine resistance. Both bromocriptine and pimozide have been approved by the FDA for several years, and no obvious side effects and pharmaceutical incompatibility of the two drugs has been reported (10). The results of the present study indicated that concurrent blockade of both pathways may be efficacious, but at the expense of possible toxicity, which requires further investigation. It is known that pimozide may cause signs of an allergic reaction: Urticaria, swelling of your face, lips, tongue (45). Bromocriptine may cause some unwanted effects including dizziness and nausea (46). Patients should be informed of these possible side effects, and get emergency medical help if they have relevant symptoms.

The results of the present study support the use of pimozide as a potential chemosensitizer to bromocriptine in prolactinoma-resistant patients. The results revealed that bromocriptine induced STAT5 activation, and cyclin D1 inhibition. Additionally, pimozide in combination with bromocriptine decreased p-STAT5 and Bcl-xL expression levels compared to bromocriptine monotherapy. This enhanced inhibition further reversed bromocriptine resistance in prolactinoma cells. The schematic model that summarizes the proposed mechanisms of pimozide in prolactinoma bromocriptine resistance is presented in Fig. 6. Based on these data, pimozide in combination with the current standard, bromocriptine, may be of interest as a potential therapeutic for the treatment of bromocriptine-resistant prolactinomas. Additional studies are required to further explore pimozide as a chemosensitizer clinically for the treatment of patients with bromocriptine-resistant prolactinomas.

\section{Acknowledgements}

The authors would like to thank Dr Junqiang Yan at the Neurotumor Laboratory of the First Affiliated Hospital of Henan University of Science and Technology (Luoyang, China) for technical support.

\section{Funding}

The present study was supported by funding from the National Natural Science Foundation of China (grant no. U1404822).

\section{Availability of data and materials}

The datasets used during the present study are available from the corresponding author upon reasonable request.

\section{Authors' contributions}

ZX designed the study and wrote the manuscript. ZX, KZ, XW and ZLi supervised the study, contributed to data acquisition and revised the manuscript. JL, QD, CS, ZLiu, XY, ZLi and ZS collected and analyzed the data, and performed the experiments. All authors read and approved the final manuscript.

\section{Ethics approval and consent to participate}

The present study was approved by the First Affiliated Hospital of Henan University of Science and Technology (HUST) Institutional Review Board (approval no. 2013-08). Written informed consent was obtained from each donor and patient. All procedures involving mice were approved by the HUST Institutional Animal Care and Use Committee and performed in accordance with the National Institutes of Health Guide for the Care and Use of Laboratory Animals, 8th edition, 2011.

\section{Patient consent for publication}

Not applicable.

\section{Competing interests}

The authors declare that they have no competing interests.

\section{References}

1. Mete O, Cintosun A, Pressman I and Asa SL: Epidemiology and biomarker profile of pituitary adenohypophysial tumors. Mod Pathol 31: 900-909, 2018.

2. Liu J, He Y, Zhang X, Yan X and Huang Y: Clinicopathological analysis of 250 cases of pituitary adenoma under the new WHO classification. Oncol Lett 19: 1890-1898, 2020.

3. Lim CT and Korbonits M: Update on the clinicopathology of pituitary adenomas. Endocr Pract 24: 473-488, 2018.

4. Tang C, Sun R, Wen G, Zhong C, Yang J, Zhu J, Cong Z, Luo X and Ma C: Bromocriptine and cabergoline induce cell death in prolactinoma cells via the ERK/EGR1 and AKT/mTOR pathway respectively. Cell Death Dis 10: 335, 2019.

5. Molitch ME: Pharmacologic resistance in prolactinoma patients. Pituitary 8: 43-52, 2005.

6. Kavarthapu R and Dufau ML: Essential role of endogenous prolactin and CDK7 in estrogen-induced upregulation of the prolactin receptor in breast cancer cells. Oncotarget 8: 27353-27363, 2017.

7. Clevenger CV, Gadd SL and Zheng J: New mechanisms for PRLr action in breast cancer. Trends Endocrinol Metab 20: 223-229, 2009.

8. Gorvin CM, Newey PJ, Rogers A, Stokes V, Neville MJ, Lines KE, Ntali G, Lees P, Morrison PJ, Singhellakis PN, et al: Association of prolactin receptor (PRLR) variants with prolactinomas. Hum Mol Genet 28: 1023-1037, 2019.

9. Kwinta BM, Grzywna E, Krzyżewski RM and Adamek D: The quantitative evaluation of the immunohistochemical expression of the pituitary adenomas. Folia Med Cracov 57: 83-96, 2017. 
10. Naguy A: Pimozide: An old wine in a new bottle. Indian J Psychol Med 39: 382-383, 2017.

11. Preskorn SH: Changes in the product label for pimozide illustrate both the promises and the challenges of personalized medicine. J Clin Psychiatry 73: 1191-1193, 2012.

12. Friedman JI, Lindenmayer JP, Alcantara F, Bowler S, Parak M, White L, Iskander A, Parrella M, Adler DN, Tsopelas ND, et al: Pimozide augmentation of clozapine inpatients with schizophrenia and schizoaffective disorder unresponsive to clozapine monotherapy. Neuropsychopharmacology 36: 1289-1295, 2011.

13. Rondanin R, Simoni D, Maccesi M, Romagnoli R, Grimaudo S Pipitone RM, Meli M, Cascio A and Tolomeo M: Effects of pimozide derivatives on pSTAT5 in K562 cells. ChemMedChem 12 1183-1190, 2017.

14. Rondanin R, Simoni D, Romagnoli R, Baruchello R, Marchetti P, Costantini C, Fochi S, Padroni G, Grimaudo S, Pipitone RM, et al: Inhibition of activated STAT5 in Bcr/Abl expressing leukemia cells with new pimozide derivatives. Bioorg Med Chem Lett 24 4568-4574, 2014.

15. Li H, Zheng H, Sun Y, Yu Q and Li L: Signal transducer and activator of transcription 5a inhibited by pimozide may regulate survival of goat mammary gland epithelial cells by regulating parathyroid hormone-related protein. Gene 551: 279-289, 2014.

16. Chen JJ, Cai N, Chen GZ, Jia CC, Qiu DB, Du C, Liu W, Yang Y, Long ZJ and Zhang Q: The neuroleptic drug pimozide inhibits stem-like cell maintenance and tumorigenicity in hepatocellular carcinoma. Oncotarget 8: 17593-17609, 2017.

17. Zhou W, Chen MK, Yu HT, Zhong ZH, Cai N, Chen GZ, Zhang P and Chen JJ: The antipsychotic drug pimozide inhibits cell growth in prostate cancer through suppression of STAT3 activation. Int J Oncol 48: 322-328, 2016.

18. Hadzijusufovic E, Keller A, Berger D, Greiner G, Wingelhofer B, Witzeneder N, Ivanov D, Pecnard E, Nivarthi H, Schur F, et al: STAT5 is expressed in CD34 ${ }^{+} / \mathrm{CD} 38$-stem cells and serves as a potential molecular target in ph-negative myeloproliferative neoplasms. Cancers (Basel) 12: 1021, 2020.

19. Subramaniam D, Angulo P, Ponnurangam S, Dandawate P, Ramamoorthy P, Srinivasan P, Iwakuma T, Weir SJ, Chastain K and Anant S: Suppressing STAT5 signaling affects osteosarcoma growth and stemness. Cell Death Dis 11: 149, 2020.

20. Zhao Y, Jin D, Lian W, Xing B, Feng M, Liu X and Wang R: Clinical characteristics and surgical outcome of prolactinoma in patients under 14 years old. Medicine (Baltimore) 98: e14380, 2019

21. Zhao Y, Xiao Z, Chen W, Yang J, Li T and Fan B: Disulfiram sensitizes pituitary adenoma cells to temozolomide by regulating O6-methylguanine-DNA methyltransferase expression. Mol Med Rep 12: 2313-2322, 2015.

22. Turhan AG: STAT5 as a CML target: STATinib therapies. Blood 117: 3252-3253, 2011.

23. Florio T: Adult pituitary stem cells: From pituitary plasticity to adenoma development. Neuroendocrinology 94: 265-277, 2011.

24. Pastrana E, Silva-Vargas V and Doetsch F: Eyes wide open: A critical review of sphere-formation as an assay for stem cells. Cell Stem Cell 8: 486-498, 2011.

25. Würth R, Barbieri F, Pattarozzi A, Gaudenzi G, Gatto F, Fiaschi P, Ravetti JL, Zona G, Daga A, Persani L, et al: Phenotypical and pharmacological characterization of stem-like cells in human pituitary adenomas. Mol Neurobiol 54: 4879-4895, 2017.

26. Santos-Pinheiro F, Penas-Prado M, Kamiya-Matsuoka C, Waguespack SG, Mahajan A, Brown PD, Shah KB, Fuller GN and McCutcheon IE: Treatment and long-term outcomes in pituitary carcinoma: A cohort study. Eur J Endocrinol 181: 397-407, 2019.

27. Akinduro OO, Lu VM, Izzo A, De Biase G, Vilanilam G Van Gompel JJ, Bernet V, Donaldson A, Olomu O, Meyer FB, et al: Radiographic and hormonal regression in prolactinomas: An analysis of treatment failure. World Neurosurg 129: e686-e694, 2019.

28. Huang HY, Lin SJ, Zhao WG and Wu ZB: Cabergoline versus bromocriptine for the treatment of giant prolactinomas: A quantitative and systematic review. Metab Brain Dis 33: 969-976, 2018.
29. Hachim IY, Shams A, Lebrun JJ and Ali S: A favorable role of prolactin in human breast cancer reveals novel pathway-based gene signatures indicative of tumor differentiation and favorable patient outcome. Hum Pathol 53: 142-152, 2016.

30. Wen Y,ZandB, OzpolatB,Szczepanski MJ,Lu C, YucaE,Carroll AR, Alpay N, Bartholomeusz C, Tekedereli I, et al: Antagonism of tumoral prolactin receptor promotes autophagy-related cell death. Cell Rep 7: 488-500, 2014.

31. Kalita A, Gupta S, Singh P, Surolia A and Banerjee K: IGF-1 stimulated upregulation of cyclin D1 is mediated via STAT5 signaling pathway in neuronal cells. IUBMB Life 65: 462-471, 2013.

32. Mao Y, Li Z, Lou C and Zhang Y: Expression of phosphorylated Stat5 predicts expression of cyclin D1 and correlates with poor prognosis of colonic adenocarcinoma. Int J Colorectal Dis 26: 29-35, 2011

33. Brockman JL and Schuler LA: Prolactin signals via Stat5 and Oct-1 to the proximal cyclin D1 promoter. Mol Cell Endocrinol 239: 45-53, 2005.

34. Magné S, Caron S, Charon M, Rouyez MC and Dusanter-Fourt I: STAT5 and Oct-1 form a stable complex that modulates cyclin D1 expression. Mol Cell Biol 23: 8934-8945, 2003.

35. Qian YH, Xiao Q, Chen H and Xu J: Dexamethasone inhibits camptothecin-induced apoptosis in C6-glioma via activation of Stat5/Bcl-xL pathway. Biochim Biophys Acta 1793: 764-771, 2009.

36. Fujinaka Y, Takane K, Yamashita H and Vasavada RC: Lactogens promote beta cell survival through JAK2/STAT5 activation and Bcl-XL upregulation. J Biol Chem 282: 30707-30717, 2007.

37. Kanie T, Abe A, Matsuda T, Kuno Y, Towatari M, Yamamoto T, Saito H, Emi N and Naoe T: TEL-Syk fusion constitutively activates PI3-K/Akt, MAPK and JAK2-independent STAT5 signal pathways. Leukemia 18: 548-555, 2004.

38. Moldovan IM, Susman S, Pîrlog R, Jianu EM, Leucuta DC, Melincovici CS, Crişsan D and Florian IŞ: Molecular markers in the diagnosis of invasive pituitary adenomas-an immunohistochemistry study. Rom J Morphol Embryol 58: 1357-1364, 2017.

39. Bălinişteanu B, Cîmpean AM, Ceauşu AR, Corlan AS, Melnic E and Raica M: High Ki-67 expression is associated with prolactin secreting pituitary adenomas. Bosn J Basic Med Sci 17: 104-108, 2017.

40. Oshige T, Nakamura Y, Sasaki Y, Kawano S, Ohki T, Tsuruta M, Tokubuchi I, Nakayama H, Yamada K, Ashida K, et al: Bromocriptine as a potential glucose-lowering agent for the treatment of prolactinoma with type 2 diabetes. Intern Med 58: 3125-3128, 2019.

41. Gschwantler-Kaulich D, Grunt TW, Muhr D, Wagner R, Kölbl H and Singer CF: HER Specific TKIs exert their antineoplastic effects on breast cancer cell lines through the involvement of STAT5 and JNK. PLoS One 11: e0146311, 2016.

42. Hazzan T, Eberle J, Worm M and Babina M: Thymic stromal lymphopoietin interferes with the apoptosis of human skin mast cells by a dual strategy involving STAT5/Mcl-1 and JNK/Bcl-xL . Cells 8: 829, 2019.

43. Kim U, Kim CY, Lee JM, Ryu B, Kim J, Shin C and Park JH: Pimozide inhibits the human prostate cancer cells through the generation of reactive oxygen species. Front Pharmacol 10: 1517, 2020.

44. Nyga R, Pecquet C, Harir N, Gu H, Dhennin-Duthille I, Régnier A, Gouilleux-Gruart V, Lassoued K and Gouilleux F: Activated STAT5 proteins induce activation of the PI 3-kinase/Akt and Ras/MAPK pathways via the Gab2 scaffolding adapter. Biochem J 390: 359-366, 2005.

45. Gupta MA, Vujcic B, Pur DR and Gupta AK: Use of antipsychotic drugs in dermatology. Clin Dermatol 36: 765-773, 2018.

46. Biller BM: Hyperprolactinemia. Int J Fertil Womens Med 44: 74-77, 1999.

This work is licensed under a Creative Commons Attribution-NonCommercial-NoDerivatives 4.0 International (CC BY-NC-ND 4.0) License. 